Article

\title{
Synthesis and Adsorption Behavior of Microporous Iron-Doped Sodium Zirconosilicate with the Structure of Elpidite
}

\author{
Emad Elshehy
}

check for

updates

Citation: Elshehy, E. Synthesis and Adsorption Behavior of Microporous Iron-Doped Sodium Zirconosilicate with the Structure of Elpidite. Surfaces 2021, 4, 41-53. https://doi.org/ $10.3390 /$ surfaces 4010007

Academic Editor: Gaetano Granozzi Received: 23 December 2020

Accepted: 23 January 2021

Published: 10 February 2021

Publisher's Note: MDPI stays neutral with regard to jurisdictional claims in published maps and institutional affiliations.

Copyright: (C) 2021 by the author. Licensee MDPI, Basel, Switzerland. This article is an open access article distributed under the terms and conditions of the Creative Commons Attribution (CC BY) license (https:// creativecommons.org/licenses/by/ $4.0 /)$.
Nuclear Materials Authority, P.O. Box 530, El-Maadi, Cairo 11728, Egypt; eelshehy@yahoo.com; Tel.: +20-10-0819-7997

\begin{abstract}
Decontamination of water from radionuclides contaminants is a key priority in environmental cleanup and requires intensive effort to be cleared. In this paper, a microporous iron-doped zeolite-like sodium zirconosilicate (F@SZS) was designed through hydrothermal synthesis with various $\mathrm{Si} / \mathrm{Zr}$ ratios of 5,10, and 20, respectively. The synthesized materials of F@SZS materials were well characterized by various techniques such as XRD, SEM, TEM, and $\mathrm{N}_{2}$ adsorption-desorption measurements. Furthermore, the F@SZS-5 and F@SZS-10 samples had a crystalline structure related to the $\mathrm{Zr}-\mathrm{O}-\mathrm{Si}$ bond, unlike the F@SZS-20 which had an overall amorphous structure. The fabricated F@SZS-5 nanocomposite showed a superb capability to remove cesium ions from ultradilute concentrations, and the maximum adsorption capacity was $21.5 \mathrm{mg} \mathrm{g}^{-1}$ at natural $\mathrm{pH}$ values through an ion exchange mechanism. The results of cesium ions adsorption were found to follow the pseudo-first-order kinetics and the Langmuir isotherm model. The microporous iron-doped sodium zirconosilicate is described as an adsorbent candidate for the removal of ultra-traces concentrations of $\mathrm{Cs}(\mathrm{I})$ ions.
\end{abstract}

Keywords: zirconosilicates; zeolite structure; microporous materials; nanocomposite; cesium removal

\section{Introduction}

Zeolites are finding increasing interest in technological applications due primarily to their adsorption and catalytic behaviors. Framework structures of traditional zeolite materials like aluminosilicate and aluminophosphates are created by four-coordinate elements [1]. However, studies performed in the last decade demonstrated that many titano-, niobo-, and zirconosilicates are also able to be involved in ion exchange applications [1-5]. The synthesis of zeolitic nanostructures of another class, mostly, of silicates, which contain five and six coordinates in their frameworks like titanium (Ti), niobium $(\mathrm{Nb})$, and zirconium $(\mathrm{Zr})$ elements along with tetrahedral fractions, has attracted the growing interest of many researchers. These materials are characterized by considerable structural diversity, with a broad spectrum of physical and chemical properties such as engineered microporosity, pore volumes $\left(V_{p}\right)$, surface areas $\left(S_{A}\right)$, and surface activities [6-10].

Synthetic zeolitic microporous zirconosilicates with heteropolyhedral frameworks of tetrahedra $\mathrm{SiO}_{4}$ and octahedral $\mathrm{ZrO}_{6}$ have attracted a great deal of attention due to the prospects of their wide application in technological applications such as high-selectivity sorbents, catalysts, and ion conductors [7-11]. Most of zirconosilicate frameworks show the mobility of alkali ions with ion-exchange features and the extraordinary stability of their polyhedral configurations are due to the formation of $\mathrm{Si}-\mathrm{O}-\mathrm{Si}$ or $\mathrm{Si}-\mathrm{O}-\mathrm{Zr}$ linkages [12]. So far, the work on the synthesis of alkali zirconosilicates has been aimed primarily at modeling processes of mineral formation. In particular, analogs of a number of zeolitetype minerals are synthesized. For example, a eudialyte mineral was synthesized in a weakly alkaline aqueous medium [1]. Rocha et al. reported the synthesis of a microporous sodium zirconosilicate with the structure of the mineral petarasite [10]. Subsequently, Jale et al. reported three zirconoosilicate minerals (elpidite, umbite, and gaidonnayit), which 
contain $\mathrm{SiO}_{4}$ in tetrahedral coordination and $\mathrm{ZrO}_{6}$ in octahedral coordination [11]. On the other hand, the isomorphous substitutions of various ions as metal dopants into the zeolitic frameworks have also attracted interest over the last decade [12-19]. These metal dopants can be incorporated into the zirconosilicates frameworks, either as guest species in a solid solution or as separate phases encapsulated in the zeolite frameworks [19-21]. It has been shown that the dopants lead to changing ion-exchange activities of zeolite materials, in which the isomorphous substitutions of some ions with others have different oxidation states through incorporations into tetrahedral positions $[13,15]$. Moreover, the presence of tetrahedral zirconium ions in the octahedral coordination results in two negative charges on the framework for each of the metal ions incorporated. Overall, the synthesis of microporous zirconosilicates is rare in the literature because of the time-consumed synthesis of these materials and the lack of control on the synthetic routes for obtaining the desired structures.

The removal of radionuclides from aqueous solutions, especially cesium and strontium, has become an emerging issue for the environment after the tragedy of the Japanese nuclear power plant (Fukushima Daiichi) [22-25]. As a result, huge amounts of radionuclides were released into the environment. Particularly, cesium ions have moved out across the wastewater to surface water, creating serious environmental problems given its high mobility and its long half-life [26-28]. To date, various classes of inorganic sorbents have been developed for capturing cesium ions from aqueous solutions [22-29]. Thus, there is great interest from researchers for tailoring advanced materials that can remove the ultratraces of cesium ions in the presence of their competing ions, e.g., sodium, potassium, and rubidium ions. Toward this logarithm, there are continuous intensive efforts in tailoring radioactive-durable inorganic sorbents that can efficiently capture the radionuclides from aqueous solutions such as active zircon-/titano- phosphates and silicates owing to their efficient separation and radiation stabilities. The ion-exchange behaviors of the synthetic titano- and zirconosilicates are rather rare. It was demonstrated that zeolite-like $\mathrm{K}$ and $\mathrm{Na}$ titanosilicates prepared by the hydrothermal synthesis efficiently adsorb $\mathrm{Cs}(\mathrm{I})$ and $\mathrm{Rb}(\mathrm{I})$ ions from solutions. It was also found that various cationic forms of synthetic titanosilicates can remove trace amounts of $\mathrm{Cs}(\mathrm{II})$ and $\mathrm{Sr}$ (II) from aqueous solutions [1]. Elpidite mineral $\left(\mathrm{Na}_{2} \mathrm{ZrSi}_{6} \mathrm{O}_{15} \cdot 3 \mathrm{H}_{2} \mathrm{O}\right)$ is an example of zirconosilicate phases characterized by its active ion-exchange behavior [19].

The aim of the present study is to design a new effective microporous nanostructured iron-doped sodium zirconosilicate (F@SZS) by a simple hydrothermal method and study its adsorption behavior towards radioactive cesium ions. The textural and structural characteristics of the synthesized iron-doped zirconosilicate sorbent were examined using different analytical techniques (i.e., $\mathrm{XRD}, \mathrm{SEM}, \mathrm{TEM}$, and $\mathrm{N}_{2}$ adsorption-desorption measurements). The effects of different factors such as $\mathrm{pH}$, equilibrium time, and cesium ion concentrations on the adsorption efficiency were studied. The obtained adsorption data were applied to different isotherm models studies.

\section{Materials and Methods}

\subsection{Synthesis of the Fe-Doped Microporous Sodium Zirconosilicate Sorbent}

A copolymer surfactant-dodecyl-poly-ethylene-oxide-ether designated as Brij-35 $\left(\mathrm{CH}_{3}\left(\mathrm{CH}_{2}\right)_{11}\left(\mathrm{OCH}_{2} \mathrm{CH}_{2}\right)_{23}-\mathrm{OH}, \mathrm{Mw}=1198 \mathrm{~g} \mathrm{~mol}^{-1}\right)$, sodium silicate $\left(\mathrm{Na}_{2} \mathrm{SiO}_{3}\right)$, zirconyl chloride octa-hydrate $\left(\mathrm{ZrOCl}_{2} \cdot 8 \mathrm{H}_{2} \mathrm{O}\right.$,), iron(III) citrate $\left(\mathrm{C}_{6} \mathrm{H}_{5} \mathrm{FeO}_{7}\right)$, urea $\left(\mathrm{CO}\left(\mathrm{NH}_{2}\right)_{2}\right)$, and hydrofluoric acid (HF) were obtained from Sigma-Aldrich Pty Ltd. Iron-doped sodium zirconosilicates with different mole ratios of $\mathrm{Zr} / \mathrm{Si}$ were synthesized by dissolving $1 \mathrm{~g}$ of $\mathrm{ZrOCl}_{2} \cdot 8 \mathrm{H}_{2} \mathrm{O}\left(4.1 \times 10^{-2} \mathrm{M}\right), 0.15 \mathrm{~g}$ iron citrate $\left(8.1 \times 10^{-3} \mathrm{M}\right), 1.5 \mathrm{~mL} \mathrm{HF}(38 \%)$, and $1.6 \mathrm{~g}$ Brij-35 in de-ionized water (DIW) and stirring them at room temperature for $30 \mathrm{~min}$, and then sodium silicate $\left(\mathrm{Na}_{2} \mathrm{SiO}_{3}\right)$ was introduced into a precursor solution with different ratios $(0.2,0.4$, and $0.8 \mathrm{M})$. The solution was kept under constant stirring at $65^{\circ} \mathrm{C}$ for $1 \mathrm{~h}$. Then, $1.2 \mathrm{~g}$ of urea $(0.27 \mathrm{M})$ was added with continuous stirring, until the $\mathrm{pH}$ value of the solution reached 8 . The reaction mixture was moved to a $100 \mathrm{~mL}$ Teflon-lined stainless 
steel autoclave. Crystallization was carried out at $200{ }^{\circ} \mathrm{C}$ for $140 \mathrm{~h}$. The precipitate was collected by filtration and washed several times with DIW and ethanol to remove the remaining agents. Finally, the as-synthesized iron-doped sodium zirconosilicates were dried at $80^{\circ} \mathrm{C}$ for $12 \mathrm{~h}$ in a vacuum oven and carefully calcined in the air at a heating rate of $2{ }^{\circ} \mathrm{C} \mathrm{min}^{-1}$ to increase the temperature from room temperature up to $550{ }^{\circ} \mathrm{C}$ for $5 \mathrm{~h}$, in order to remove the surfactant and obtain microporous iron-sodium zirconium silicate composites with a different structure (F@SZS). Here, F@SZS-20, F@SZS-10, and F@SZS-5 represent the synthesized $\mathrm{Zr} / \mathrm{Si}$ composites with $\mathrm{Si} / \mathrm{Zr}$ mole ratios of 5, 10, and 20 , respectively.

\subsection{Adsorption Assessment}

The adsorption experiments were carried out using the batch method to evaluate the adsorption activities of the synthesized materials toward cesium ions from aqueous solutions. The Cs(I) ions and other metal ion-standard solutions were obtained from Wako Company Ltd. (Osaka, Japan). Fifty milligrams of each of the aforementioned F@SZS materials with different $\mathrm{Si} / \mathrm{Zr}$ molar ratios were added to $25 \mathrm{~mL}$ solutions with $50 \mathrm{mg}$ $\mathrm{L}^{-1}$ cesium at different $\mathrm{pH}$ values ranged from 2 to 11 that can be adjusted using diluted hydrochloric acid and sodium hydroxide. After shaking for an appropriate time at $25^{\circ} \mathrm{C}$, the porous F@SZS sorbents were collected by filtration. The concentrations of the cesium ions in the aqueous solution before and after sorption into porous F@SZS materials were determined using inductively coupled plasma atomic emission spectroscopy (ICP-AES). The adsorption capacity, $q_{e}\left(\mathrm{mg} \mathrm{g}^{-1}\right)$, was calculated as following [27]:

$$
q_{e}=\frac{\left(C_{i}-C_{e}\right) V}{m}
$$

where $C_{i}$ and $C_{e}$ are the initial concentration and the equilibrium concentration of cesium ions ( $\left.\mathrm{mg} \mathrm{L}^{-1}\right)$, respectively, $V$ is the volume of the testing solution $(\mathrm{L})$, and $m$ is the amount of the synthesized F@SZSs materials (g). The effects of interfering ions, namely; $\mathrm{Na}(\mathrm{I}), \mathrm{K}(\mathrm{I})$, $\mathrm{Rb}(\mathrm{I}), \mathrm{Mg}(\mathrm{II}), \mathrm{Ca}(\mathrm{II}), \mathrm{Sr}(\mathrm{II}), \mathrm{Fe}(\mathrm{III}), \mathrm{Ni}(\mathrm{II}), \mathrm{Cr}(\mathrm{III}), \mathrm{Zn}(\mathrm{II}), \mathrm{La}(\mathrm{III}), \mathrm{U}(\mathrm{VI}), \mathrm{Th}(\mathrm{IV}), \mathrm{Cu}(\mathrm{II}), \mathrm{Ba}(\mathrm{II})$, $\mathrm{Al}(\mathrm{III})$, and $\mathrm{Pb}(\mathrm{II})$, on Cs(I) ions in F@SZS-5 were tested. A Cs(I) ion concentration of $0.5 \mathrm{mg}$ $\mathrm{L}^{-1}$ and an interfering ions concentration of $2 \mathrm{mg} \mathrm{L}^{-1}$ were used to evaluate the adsorption feasibility of cesium in low concentrations in the same manner according to the sorption experiments from pure solutions.

\section{Results and Discussion}

\subsection{Characterization of the Synthesized Materials}

The phase structures, crystallinities, and morphologies of the synthesized F@SZS materials are key factors for its application as sorbents towards the remediation of metal ions from aqueous solutions. The chemical structures of the synthesized zirconosilicates were examined by XRD with a Philips X-ray generator model PW 3710/31. The intense diffraction peaks indicated the crystalline nature of both the as-synthesized F@SZS-5 and F@SZS-10 materials. Figure 1a-c shows the XRD patterns of all the synthesized F@SZS materials with different molar ratios calcined at $550{ }^{\circ} \mathrm{C}$. Wide diffraction peaks were observed for the F@SZS-20 sample, indicating the formation of amorphous structures. Five small peaks at $2 \theta=13.02^{\circ}, 21.5^{\circ}, 27.55^{\circ}, 35.2^{\circ}, 44.3^{\circ}$, and $48.4^{\circ}$ corresponding to $\left(\begin{array}{lll}1 & 0 & 0\end{array}\right)$, (1 2 2), (0 4 2), (2 04 4), (2 60 ), and (0 6 5) planes, respectively. These results revealed that the synthesized F@SZS materials were in the form of elpidite mineral $\left(\mathrm{H}_{6} \mathrm{Na}_{2} \mathrm{O}_{18} \mathrm{Si}{ }_{6} \mathrm{Zr}\right)$ with a structure assigned as a pure orthorhombic $\mathrm{Pbcm}$ space group containing double $\mathrm{Si}_{6} \mathrm{O}_{15}$ chains and segregated $\mathrm{ZrO}_{6}$ octahedra with the following unit-cell parameters: $\mathrm{a}=7.140 \AA$, $\mathrm{b}=14.680 \AA, \mathrm{c}=14.650 \AA$ ) , occupied by $\mathrm{Na}^{+}$cations and $\mathrm{H}_{2} \mathrm{O}$ molecules $[1,13-19]$. The XRD peak intensity of F@SZS-20 was not observed due to the presence of amorphous silica. The finding that the XRD patterns of all samples were different with respect to relative intensity indicated that the $\mathrm{SiO}_{2}$ ratios induced these changes. The insertion of $\mathrm{Fe}^{3+}$ ions into the zirconosilicate matrix was not detected as a new phase, because the avail- 
able concentration was considered low [20,21]. Moreover, The XRD pattern of $\mathrm{Fe}-\mathrm{Zr}-\mathrm{O}$ composite (Figure 1a-c) was similar to that of $\mathrm{ZrO}_{2}$, with only some minor differences in structure [15-18]. Furthermore, the recorded patterns of the F@SZS materials displayed a considerable shift of the main peaks to higher $2 \theta$ values, which can be owing to the contraction of the microphase. In conclusion, the crystal structures of the synthetic microporous materials exhibited interpretation difficulties due to crystal imperfection and doped ions in addition to the contamination with the synthesized by-products.
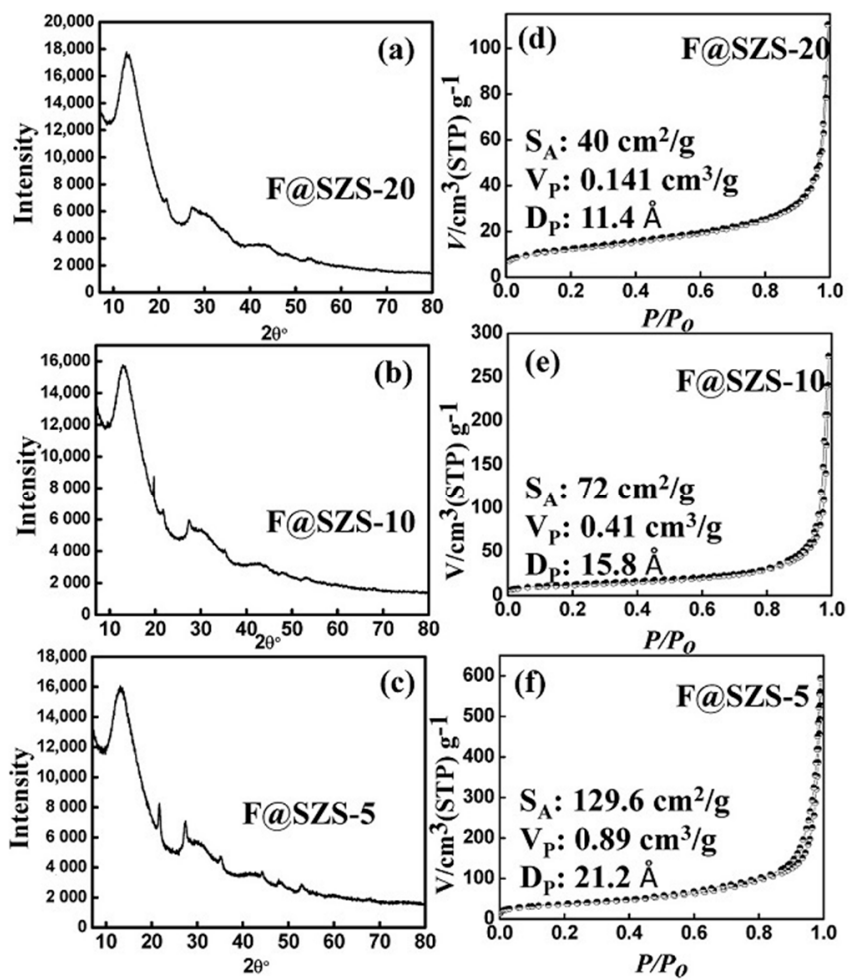

Figure 1. Representative XRD patterns $(\mathbf{a}-\mathbf{c})$ and nitrogen adsorption/desorption isotherms $(\mathbf{d}-\mathbf{f})$ for F@SZS-5, F@SZS-10, and F@SZS-20 after calcination at $550{ }^{\circ} \mathrm{C}$ for $5 \mathrm{~h}$.

The surface area $\left(\mathrm{S}_{\mathrm{A}}\right)$, pore volume $\left(\mathrm{V}_{\mathrm{p}}\right)$, and pore size $\left(\mathrm{D}_{\mathrm{p}}\right)$ of the F@SZS nanocomposites were obtained from the nitrogen adsorption-desorption isotherms of the F@SZS nanocomposites with different $\mathrm{Si} / \mathrm{Zr}$ molar ratios using the nitrogen adsorption-desorption method at $77 \mathrm{~K}$ with a BELSORP MIN-II analyzer (JP. BEL Co. Ltd., Osaka, Japan). The surface area of F@SZS-5, F@SZS-10, and F@SZS-20 were found to be 129.6, 72, and $40 \mathrm{~m}^{2} \mathrm{~g}^{-1}$, respectively, and the average pore openings calculated from desorption data by the $\mathrm{BJH}$ method (Barrett, Joyner, and Halenda) were 2.12, 1.58, and 1.14 nm for F@SZS-5, F@SZS-10, and F@SZS-20, respectively (Figure 1d-f). This means that these three materials can be roughly considered microporous materials consisting predominantly of cylindrical pores with a defined pore width and the pore width decreased with increasing $\mathrm{Zr} / \mathrm{Si}$ ratios. Therefore, these iron-doped sodium zirconosilicate nanozeolitic materials with different texture properties have different adsorption capacities of $\mathrm{Cs}(\mathrm{I})$ ions.

SEM images were obtained using a scanning electron microscope, JSM-T20, manufactured by JEOL Ltd. (Tokyo, Japan) to analyze the crystalline features and morphologies of the F@SZS materials and. The nanorods with an iron-doped sodium zirconosilicate structure were observed. Figure 2a presents the grain structure of the F@SZS-5 material with different magnifications. It is clearly seen that the F@SZS-5 sample showed a dense structure along with some degree of agglomeration. The distribution of grains with rod-like shapes along with some degree of agglomeration was observed, and the estimated size was $70 \mathrm{~nm}$. High-resolution transmission electron microscopy (HR-TEM) was performed using a JEOL JEM model 2100F transmission electron microscope. The HR-TEM images of the 
calcined F@SZS-5 showed distinct uniform pores (Figure 2b). To investigate whether iron was successfully doped into zirconosilicate particles, elemental mapping and chemical analysis was conducted using scanning transmission electron microscopy-energy-dispersive X-ray spectroscopy (STEM-EDS) mapping (Figure 3). In the elemental mapping of the iron-doped sodium zirconosilicate nanocomposite (Figure 3), the uniform distributions of $\mathrm{Zr}, \mathrm{Si}, \mathrm{Na}, \mathrm{O}$, and Fe elements can be clearly observed, which is consistent with the morphology of the composite. The EDS analysis of the F@SZS-5 indicated the presence of $\mathrm{Zr}(16.20 \%), \mathrm{Si}(27.48 \%), \mathrm{Fe}(5.96 \%), \mathrm{O}(54.9 \%)$, and $\mathrm{Na}(2.8 \%)$ in the composition domain of the F@SZS-5 microstructure (Figure 3d). In comparison, Figure 4 shows the elemental mapping and the chemical compositions of the F@SZS-20 material (i.e., $\mathrm{Si} / \mathrm{Zr}$ ratio $=20$ ). The EDS analysis indicated the presence of $\mathrm{Zr}(2.6 \%)$, Si (38.38\%), $\mathrm{Fe}(6.19 \%), \mathrm{O}(52.20 \%)$, and $\mathrm{Na}(0.98 \%)$ in the composition domain of the F@SZS-20 microstructure. Our finding that a high $\mathrm{Si} / \mathrm{Zr}$ ratio leads to the formation of a low content of zirconosilicate and a high content of silicon dioxide.
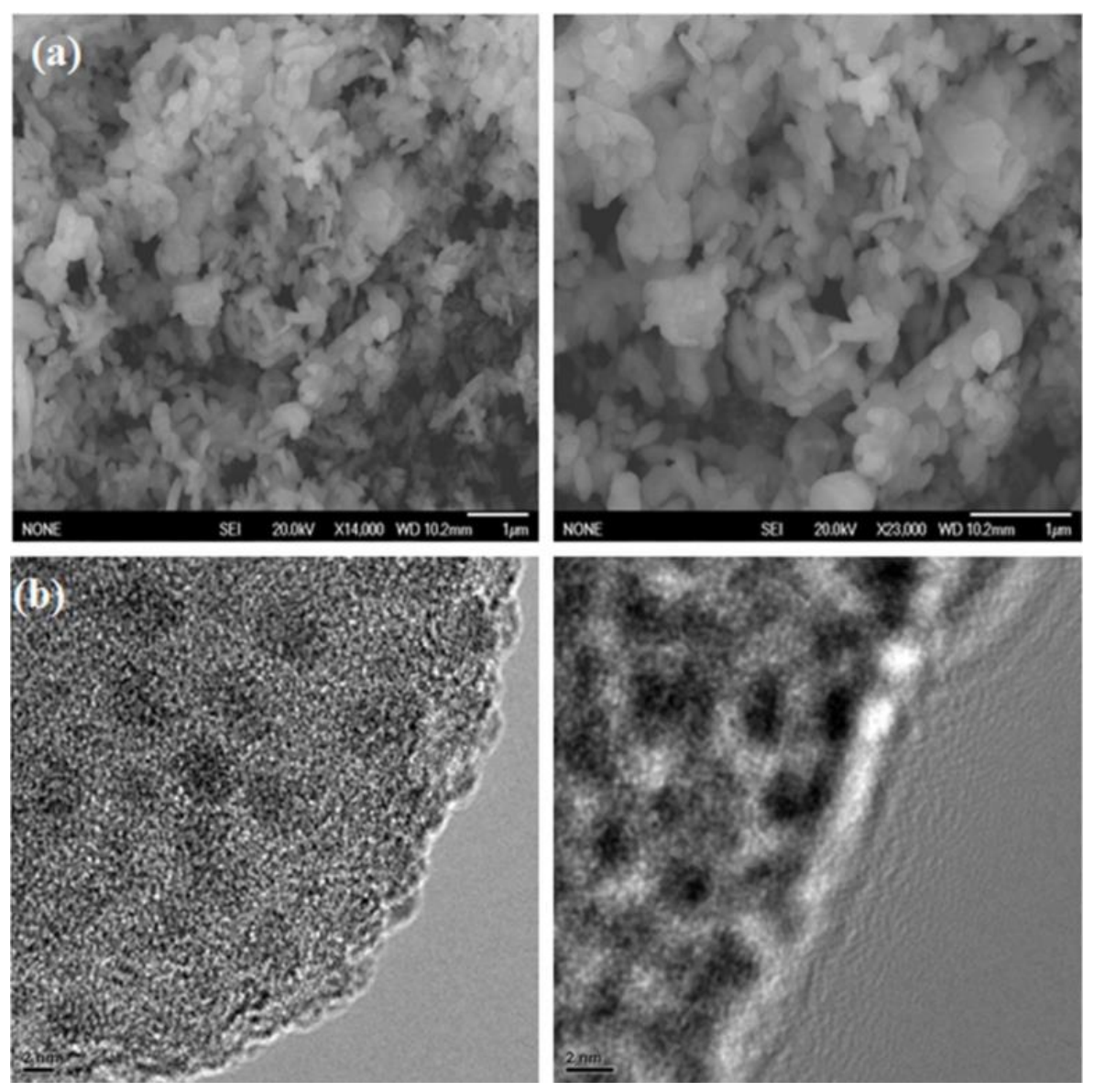

Figure 2. SEM (a) HR-TEM (b) images of the microporous F@SZS-5 with different magnifications. 


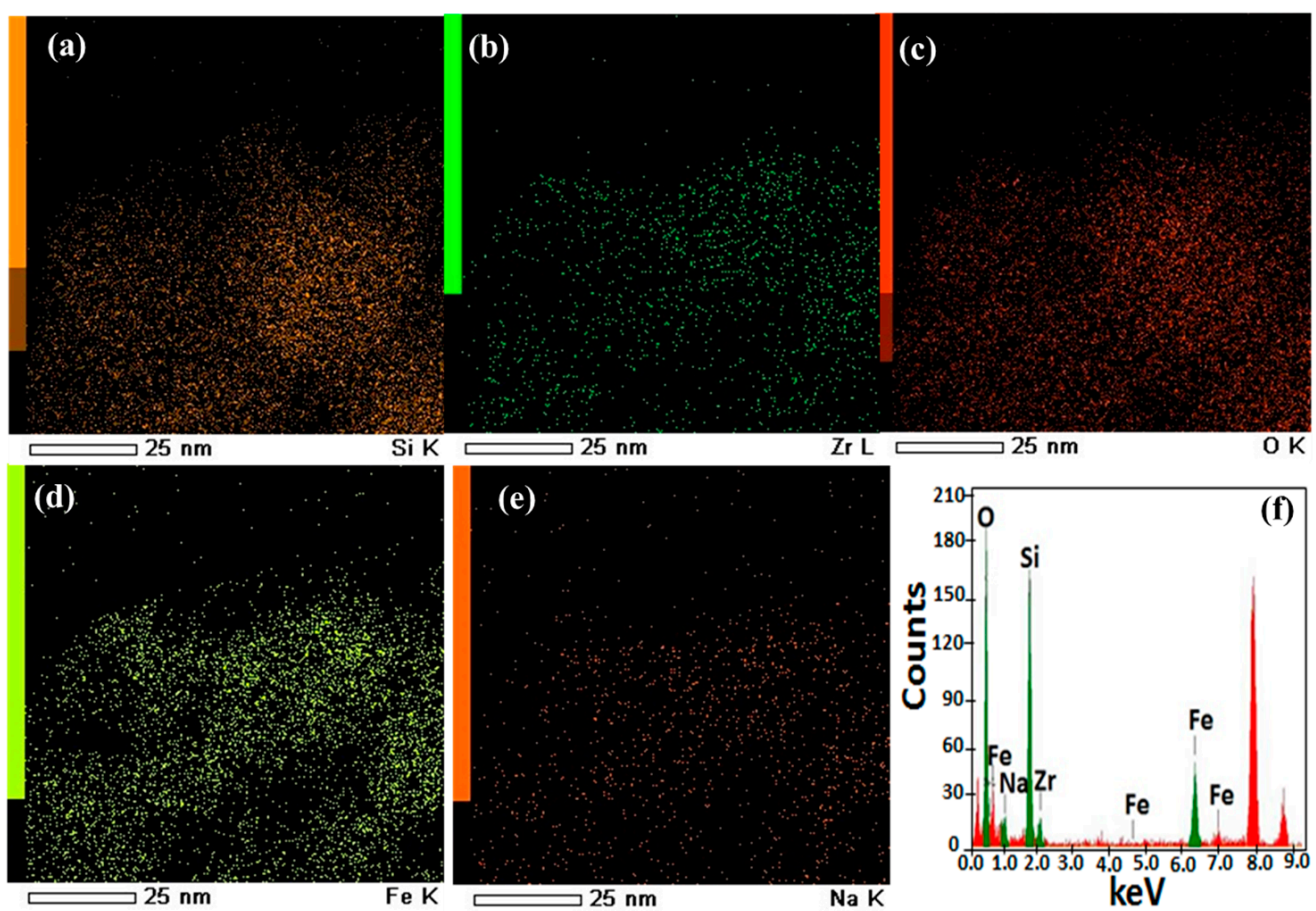

Figure 3. STEM images of the microporous F@SZS-5 sorbent with the distributions of silicon (a), zirconium (b), oxygen (c), iron (d), and sodium (e). (f) EDS analysis results and the calculated values of the atomic abundance of the species present in the solid F@SZS- 5 sorbent.

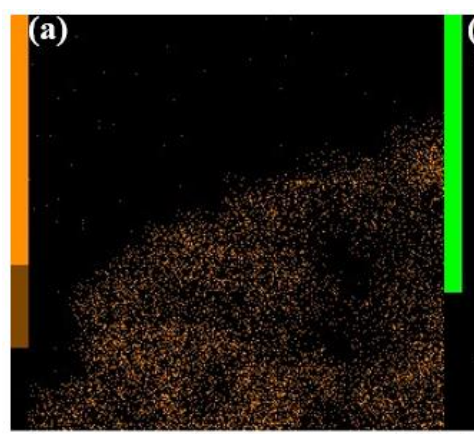

\section{(b)}

(c)

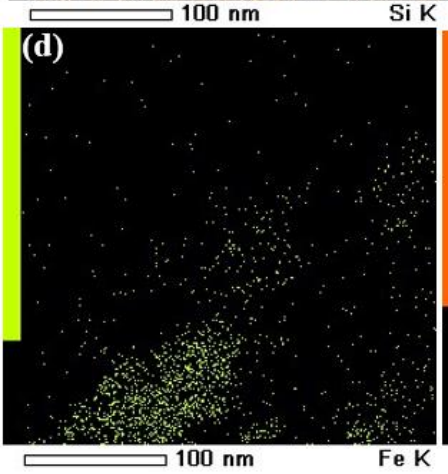

SiK

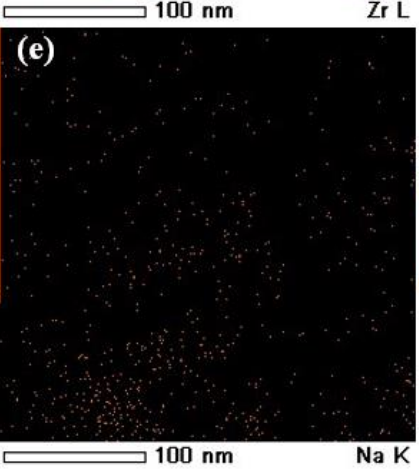

$\mathrm{Zr} \mathrm{L} \rightleftharpoons 100 \mathrm{~nm}$

$\mathrm{OK}$

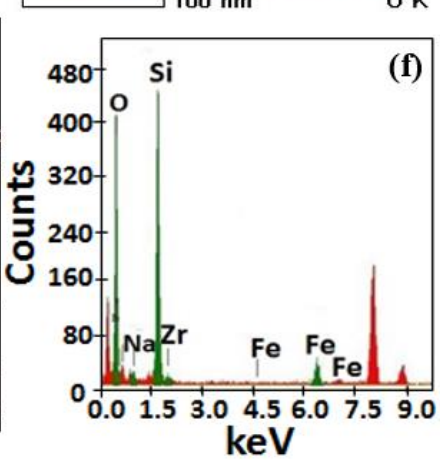

Figure 4. STEM images of the microporous F@SZS-20 material with the distributions of silicon (a), zirconium (b), oxygen (c), iron (d), and sodium (e). (f) EDS analysis results and the calculated values of the atomic abundance of the species present in the solid F@SZS-20 material.

\subsection{Adsorptive Properties of the Synthesized Materials}

To understand the affinity of $\mathrm{Na}_{2} \mathrm{ZrSi}_{6} \mathrm{O}_{15} \cdot 3 \mathrm{H}_{2} \mathrm{O}$ doped with Fe for metal ions adsorption, the synthesized materials, i.e., F@SZS-5, F@SZS-10, and F@SZS-20, were evaluated for $\mathrm{Cs}(\mathrm{I})$ ions adsorption over the $\mathrm{pH}$ ranged from 1.0 to 11.0. The acidity of the solution affected both the electrical charge on the surfaces of the iron-doped sodium zirconosilicate 
materials (F@SZS-5, F@SZS-10, and F@SZS-20) and the types of cesium species in the solutions. As shown in Figure 5a, the adsorption capacities of Cs ${ }^{+}$on F@SZS-5, F@SZS-10, and F@SZS-20 kept roughly constant in the $\mathrm{pH}$ range of 4.0-10.0. However, as the $\mathrm{pH}$ value was decreased $(\mathrm{pH}<4)$ or increased to the strongly basic region $(\mathrm{pH}>9)$, a sudden decrease in the adsorption capacity was observed. The $\mathrm{Cs}(\mathrm{I})$ ion exchange in the acidic medium was suppressed due to the excessive hydronium ions $\left(\mathrm{H}_{3} \mathrm{O}^{+}\right)$near the surface which competed with Cs(I) ions in the F@SZS active site, while the decrease of the uptake of $\mathrm{Cs}(\mathrm{I})$ ions at $\mathrm{pH}$ beyond 10 may be explained by the formation of soluble $\mathrm{CsOH}[24,25]$. All subsequent adsorption experiments of $\mathrm{Cs}(\mathrm{I})$ ions were performed on F@SZS-5, taking into consideration its highest performance in cesium adsorption among the synthesized F@SZS materials.
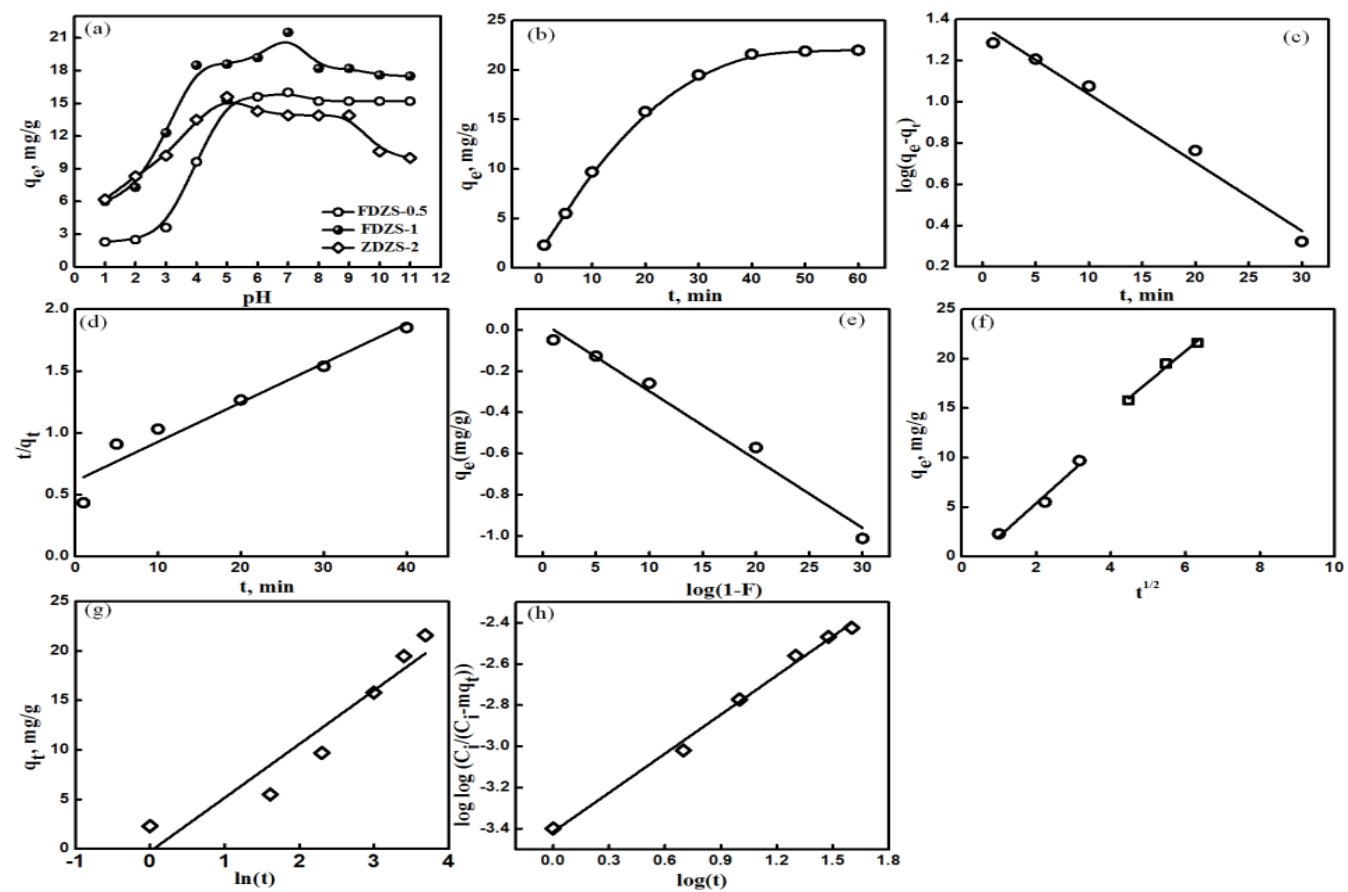

Figure 5. Effect of $\mathrm{pH}(\mathbf{a})$, time (b), the PFORE model (c), the PSORE model (d), the liquid film diffusion model (e), the Weber-Morris model (f), the Elovich model (g), and Bangham's model (h) plots for the adsorption of $\mathrm{Cs}(\mathrm{I})$ ions onto the F@SZS-5 material.

The effect of contact time on the adsorption capacity of the F@SZS-5 sample is important in determining the adsorption rate of $\mathrm{Cs}(\mathrm{I})$ ions to define the optimum operating conditions. The adsorption of Cs(I) ions onto F@SZS-5 was studied within a time period of 1-120 min at $25{ }^{\circ} \mathrm{C}$ in a single solution system. The uptake of Cs(I) ions by F@SZS-5 was initially increased by increasing the contact time, until it reached the maximum capacity. Within the first $10 \mathrm{~min}$, the adsorption efficiency of Cs(I) ions exhibited $44.9 \%$ of the total adsorption capacity (Figure 5b). The adsorption efficiency was higher in the adsorption onset because of the availability of dense active sites as well as porous features that smoothed the mobility of $\mathrm{Cs}(\mathrm{I})$ ions inside the micro-channels of the F@SZS-5 material. In a pure solution of $50 \mathrm{mg} \mathrm{L}^{-1} \mathrm{Cs}(\mathrm{I})$ ions and $50 \mathrm{mg}$ of S@SZS-5 at pH 7 and $25^{\circ} \mathrm{C}$, the equilibrium was attained after $60 \mathrm{~min}$. To know the controlling mechanism of the adsorption process, the time/adsorption data were applied to frequently applied kinetic models such as the pseudo-first-order model (PFORE) and the pseudo-second-order model (PSORE) [30,31], which can be written as following:

$$
\log \left(q_{e}-q_{t}\right)=\log q_{e}-\frac{k_{1}}{2.303} t
$$




$$
\frac{t}{q_{t}}=\frac{t}{q_{e}}+\frac{1}{k_{2} q_{e}^{2}}
$$

where $q_{e}$ and $k_{1}$ indicating the adsorption capacity at equilibrium and the PFORE rate constant, respectively, were obtained by the linear regression analysis of $\log \left(q_{e}-q_{t}\right)$ versus $\mathrm{t}$ (Figure 5c). The time/adsorption data were also fitted into the PSORE model, which shows the occurrence of the chemisorption including the adsorption steps involving external and internal diffusion. The plotting of $t / q_{t}$ vs. $t$ shown in Figure $5 \mathrm{~d}$ gave a straight line with a slope and an intercept, from which $k_{2}\left(\mathrm{~g} \mathrm{mg}^{-1} \mathrm{~min}^{-1}\right)$ and $q_{e}$ were calculated (Table 1$)$. The determination coefficient $\left(\mathrm{R}^{2}\right)$ for the PFORE model (0.978) was relatively higher than that of the PSORE model (0.925). In addition, the calculated $q_{e}$ from the PFORE model (23.44 $\mathrm{mg} \mathrm{g}^{-1}$ ) was closer to the experimental value compared to that from the PSORE model (32.2 $\left.\mathrm{mg} \mathrm{g}^{-1}\right)$ that crucially overrated the equilibrium capacity of the overall process. It is, thus, hard to differentiate between the two studied models. To gain an accurate and deep understanding of the adsorption kinetic behavior of $\mathrm{Cs}(\mathrm{I})$ on the microporous F@SZS-20, the adsorption/time data were further applied to the models. McKay liquid film diffusion model [31] supposes that the adsorption of metal ions is controlled by the film and particle diffusion (Equation (4)), in which Cs(I) ions moves out across the bulk solution towards the microchannels of F@SZS-20, and boundary layer might have a key role in this process.

$$
\begin{gathered}
\log (1-F)=-K_{d f} / 2.303 t, \\
q_{e}=x+K_{i} t^{1 / 2}, \\
q_{t}=\frac{1}{\beta} \ln (\alpha \beta)+\frac{1}{\beta} \ln (t) .
\end{gathered}
$$

\begin{tabular}{|c|c|c|}
\hline Kinetic Models & \multicolumn{2}{|c|}{ Kinetic Parameters } \\
\hline \multirow{4}{*}{ PFORE } & $q_{1} \mathrm{mg} \mathrm{g}^{-1}$ & 23.44 \\
\hline & $K_{1} \min ^{-1}$ & 0.076 \\
\hline & $R_{a d j}^{2}$ & 0.9785 \\
\hline & $R^{2}$ & 0.989 \\
\hline \multirow{4}{*}{ PSORE } & $q_{2} \mathrm{mg} \mathrm{g}^{-1}$ & 32.2 \\
\hline & $K_{2} \mathrm{mg}^{-1} \min ^{-1}$ & $1.5 \times 10^{-3}$ \\
\hline & $R_{a d j}^{2}$ & 0.9242 \\
\hline & $R^{2}$ & 0.9546 \\
\hline \multirow{3}{*}{ Liquid film diffusion } & $K_{d f} \min ^{-1}$ & 0.076 \\
\hline & $R_{a d j}^{2}$ & 0.9785 \\
\hline & $R^{2}$ & 0.9892 \\
\hline \multirow{4}{*}{ Weber-Morris diffusion } & $\left.K_{i p}, \mathrm{mg} \mathrm{g}^{-1} \min ^{-0.5}\right)$ & 3.37 \\
\hline & $X$ & -1.36 \\
\hline & $R_{a d j}^{2}$ & 0.9489 \\
\hline & $R^{2}$ & 0.9744 \\
\hline \multirow{4}{*}{ Elovich kinetic } & $\beta\left(\mathrm{g} \mathrm{mg}^{-1}\right)$ & 0.185 \\
\hline & $\alpha\left(\mathrm{mg} \mathrm{g}^{-1} \min ^{-1}\right)$ & 5.14 \\
\hline & $R_{a d j}^{2}$ & 0.889 \\
\hline & $R^{2}$ & 0.9335 \\
\hline \multirow{4}{*}{ Bangham kinetic } & $K_{b}\left(\mathrm{~mL} \mathrm{~g}^{-1} \mathrm{~L}^{-1}\right)$ & 2.29 \\
\hline & $\alpha$ & 0.63 \\
\hline & $R_{a d j}^{2}$ & 0.9926 \\
\hline & $R^{2}$ & 0.9955 \\
\hline
\end{tabular}

Table 1. Kinetic parameters for the adsorption of Cs(I) ions onto microporous F@SZS-5 sorbent.

The plotting of $\log (1-F)$ against $t$ gives a straight line with an intercept close to zero, where $F$ is the fractional attainment at equilibrium (i.e., $F=q_{t} / q_{e}$ ) [30]. This elucidates that the adsorption of $\mathrm{Cs}(\mathrm{I})$ ions onto the microporous F@SZS-5 might be controlled by the diffu- 
sion through the liquid film at the F@SZS-5 interface (Figure 5e). The rate constant for liquid film diffusion $\left(K_{d f}\right)$ was found to be $0.076 \mathrm{~min}^{-1}$. Furthermore, the time dependence data of Cs(I) ions adsorption onto the microporous F@SZS-5 was modeled by the Weber-Morris model [32] to know whether intra-particle diffusion or film diffusion is a rate-determining step (Equation (5)). From plotting $t^{0.5}$ against $q_{e}$, the intera-particle diffusion rate constant $\left(K_{i}\left(\mathrm{mg} \mathrm{g}^{-1} \mathrm{~min}^{-0.5}\right)\right)$ and the constant proportional to the boundary layer thickness $(x)$ can be determined (Figure 5f). Given the higher determination coefficient value $\left(R^{2}\right)$, the adsorption of Cs(I) ions onto the microporous F@SZS-5 sorbent was controlled by an intra-particle diffusion mechanism. Moreover, the Elovich model [30] is useful, if the interaction of $\mathrm{Cs}(\mathrm{I})$ ions on the F@SZS-5 surface active site is a rate-determining step. In the Elovich model, the initial adsorption rate $\left(\alpha ; \mathrm{mg} \mathrm{g}^{-1} \mathrm{~min}^{-1}\right)$ and the adsorption constant $(\beta$; $\mathrm{g} \mathrm{mg}^{-1}$ ) were obtained by plotting $q_{t}$ against $\ln (\mathrm{t})$ using Equation (6) (Figure $5 \mathrm{~g}$ ). The large difference between the value of $\alpha\left(5.14 \mathrm{mg} \mathrm{g}^{-1} \mathrm{~min}^{-1}\right)$ and the value of $q_{m}\left(0.35 \mathrm{mg} \mathrm{g}^{-1}\right.$ $\mathrm{min}^{-1}$ ) showed that the Elovich model did not describe the adsorption of Cs(I) ions onto F@SZS-5 and the chemical reaction was not a rate-determining step. The Bangham's model is also useful to describe the adsorption of Cs(I) ions onto the microporous F@SZS-5, in which the diffusion of Cs(I) ions into the micropores of the F@SZS-5 particles is a ratedetermining step. In the Bangham's model, $\mathrm{B}$ and $\mathrm{K}_{\mathrm{B}}\left(\mathrm{mL} \mathrm{g}^{-1} \mathrm{~L}^{-1}\right)$ are Bangham constants and $A$ is the weight of F@SZS-5 per unit volume of Cs(I) ions solution $\left(\mathrm{g} \mathrm{L}^{-1}\right)$; the straight nature with a high determination coefficient value (Figure $5 \mathrm{~h}$ ) represented that the pore diffusion-controlled adsorption process. Our findings that Ho and McKay, Weber and Morris, and Bangham's models are applicable to characterize the Cs(I) ions adsorption onto the microporous F@SZS-5 sorbent, and this was supported by the obtained statistical indices (Table 1). In the kinetic studies, the process occurs throughout the crystal bulk, and the intensity of saturation depends on local inhomogeneities of the crystal rather than on the distances of particular regions from the solution interface. This suggests that the energy barrier which ions overcome at the crystal solution interface, rather than the diffusion in the crystal bulk, is a rate-determining step. Therefore, the ion-exchange process has been improved by subjecting the solid particle surface to the corresponding dopants [1].

The overall Cs(I) adsorption capacities of F@SZS-5 at different concentrations were studied, as shown in Figure 6a. The adsorption curve indicates that the adsorption capacity of $\mathrm{Cs}(\mathrm{I})$ ions increased with the increasing of initial concentrations. At lower concentrations, the number of ions in the solution was smaller compared to that in the available sites on the mesoporous F@SZS-5. However, at higher concentrations, the available active sites were decreased, which in turn decreased the adsorption efficiency of Cs(I) ions. Figure 6a shows that the adsorption of Cs(I) ions onto F@SZS-5 was an L-type isotherm and the equilibrium was achieved, where the maximum adsorption capacity is $21.5 \mathrm{mg} \mathrm{g}^{-1}$. A comparative study in terms of the maximum adsorption capacity has been performed with other reported porous inorganic adsorbents, and the results are summarized in Table 2 [24,25,33-41]. However, the microporous F@SZS-5 is described as adsorbent candidates for the removal of high and ultra-trace concentrations of $\mathrm{Cs}(\mathrm{I})$. To evaluate the maximum uptake capacity of Cs(I) ions onto the synthesized F@SZS-5 sorbent, the surface properties, and the nature of the adsorption reaction, the adsorption data were analyzed by the most frequently applied isotherms such as Langmuir [42] and Freundlich [43] models to describe the sorption behavior of Cs(I) onto the F@SZS-5 microporous sorbent. Accordingly, the adsorption active sites inside the microchannels of the F@SZS- 5 sorbent were limited, where the Langmuir model can approach monolayer adsorption, even at high concentrations of $\mathrm{Cs}(\mathrm{I})$ ions, and involves a single reaction with constant energy of adsorption, which can be expressed as Equation (7)):

$$
\frac{C_{e}}{q_{e}}=\frac{C_{e}}{q_{L}}+\frac{1}{K_{L} q_{L}}
$$



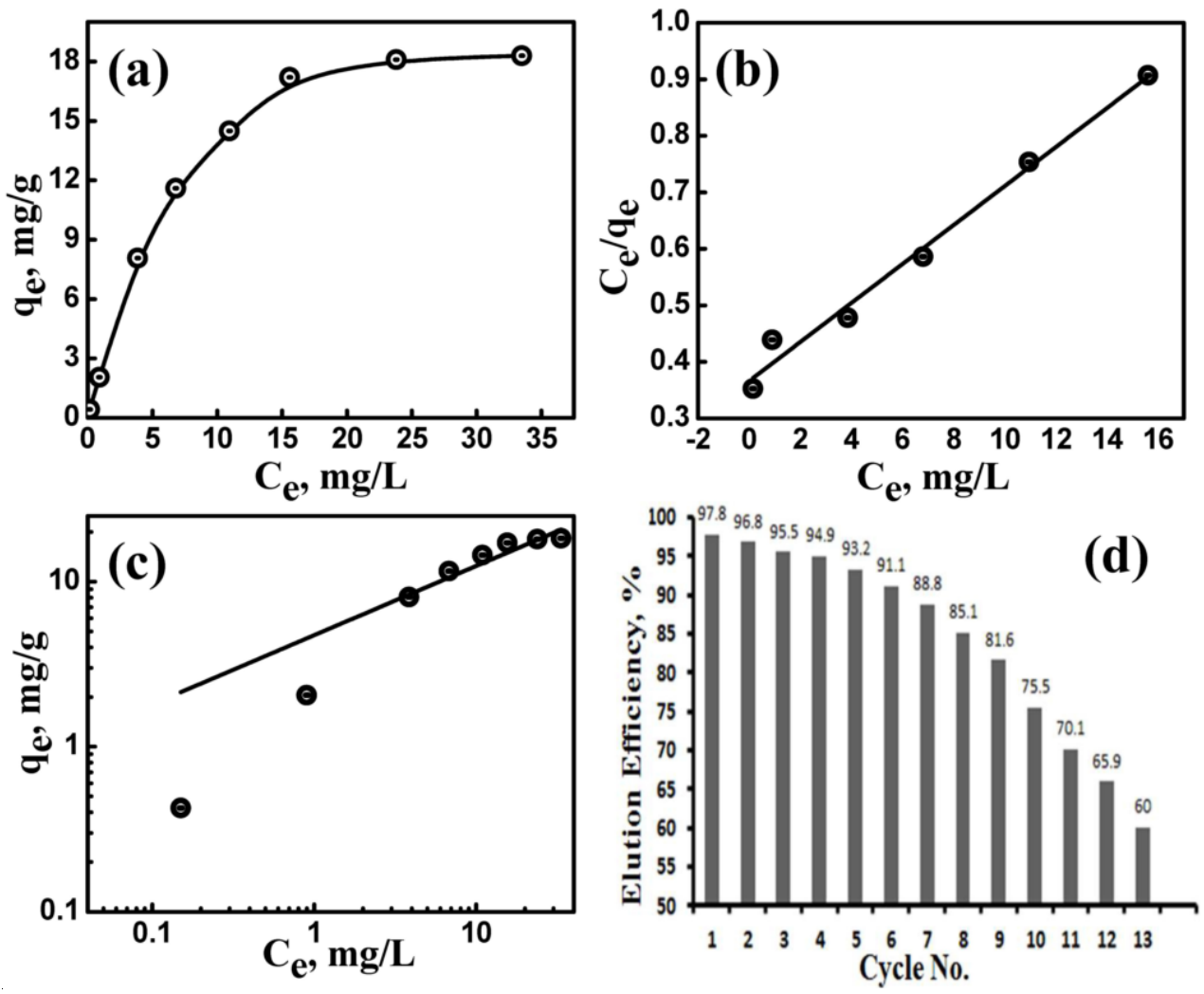

Figure 6. Adsorption isotherms of Cs(I) ions uptake by the microporous F@SZS-5 sorbent (a), Langmuir plot (b), and Freundlich isotherm (c) for the adsorption of Cs(I) ions onto F@SZS-5 micropores. Effect of the microporous F@SZS-5 sorbent on the recovery of Cs(I) ions over more than 10 cycles of sorption/desorption (d).

Table 2. Comparison of the adsorption capacities of $\mathrm{Cs}(\mathrm{I})$ ions onto various inorganic adsorbents.

\begin{tabular}{|c|c|c|c|c|c|}
\hline Adsorbent & Contact Time (Min) & $\mathrm{pH}$ & S/L Ratio ( $\left.\mathrm{g} \mathrm{L}^{-1}\right)$ & Uptake, $\left(\mathrm{mg} \mathrm{g}^{-1}\right)$ & Ref. \\
\hline Montmorillonite-prussian blue & 30 & $6.5-7.0$ & 2 & 57.47 & [34] \\
\hline Ammonium-pillared $\mathrm{MMT} / \mathrm{Fe}_{3} \mathrm{O}_{4}$ & 60 & 6.7 & 0.5 & 27.53 & [35] \\
\hline Ammonium molybdophosphate calcium alginate & 24 & $3.5-4.5$ & 100 & 91.80 & [36] \\
\hline Graphene foam/prussian blue & 720 & Natural & 2.5 & 18.67 & [37] \\
\hline Copper(II) ferrocyanide-silica & 2 & 7.8 & 0.1 & 17.10 & \\
\hline $\mathrm{Nano} \mathrm{SiO}_{2}-\mathrm{Fe}-\mathrm{CN}$ & 60 & 5.5 & 10 & 32.26 & [38] \\
\hline $\mathrm{Al}_{2} \mathrm{O}_{3}-\mathrm{ZrO}_{2}-\mathrm{CeO}_{2}$ & 60 & 6.0 & 10 & 8.88 & [39] \\
\hline Mesoporous $\mathrm{CaHPO}_{4}$ & 90 & 9.5 & 1 & 60.33 & [25] \\
\hline $\mathrm{PB} / \mathrm{Fe}_{3} \mathrm{O}_{4} / \mathrm{GO} /$ calcium alginate & 400 & 7.0 & - & 43.52 & [40] \\
\hline Ammonium-pillared MMT-CoFe $\mathrm{O}_{4} /$ calcium alginate & 120 & 6.7 & 1.0 & 86.46 & [41] \\
\hline Mesoporous HAp & 30 & 8.5 & 1.0 & 77.20 & [24] \\
\hline Mesoporous MgP & 20 & 8.5 & 1.0 & 64.00 & [42] \\
\hline F@SZS-5 & 40 & 8.0 & 1.0 & 21.50 & $\begin{array}{l}\text { This } \\
\text { work }\end{array}$ \\
\hline
\end{tabular}

Plotting $C_{e}$ against $C_{e} / q_{e}$ gives a straight line (i.e., $\mathrm{R}^{2}=0.987$ ) with a slope and an intercept equal to the maximum calculated adsorption capacity $\left(q_{L}=28.9 \mathrm{mg} \mathrm{g}^{-1}\right)$ and the Langmuir binding constant $\left(K_{L}=0.093 \mathrm{~L} \mathrm{mg}^{-1}\right)$. Our finding that the calculated values of $q_{L}$ are comparable to that of the experimental value indicated that the adsorption of Cs(I) ions onto the microporous F@SZS-5 sorbent is well-fitted with the Langmuir model (Figure $6 \mathrm{~b}$ ). The Freundlich model was also applied to estimate the adsorption processes that occur on heterogonous surfaces, where it gives an expression that describes the surface 
heterogeneity and the exponential distribution of active sites and their energies. The Freundlich model can be expressed as Equation (8):

$$
q_{e}=K_{F} C_{e}^{1 / n}
$$

where $K_{F}$ and $n$ describe the capacity $\left(\mathrm{L}^{1 / \mathrm{n}} \mathrm{mg}^{(1-1 / \mathrm{n})} \mathrm{g}^{-1}\right)$ and the intensity of the adsorption process, respectively. The results indicated that the nonlinear Freundlich model provided a good fitting (i.e., $\mathrm{R}^{2}=0.923$ ) to describe the adsorption of $\mathrm{Cs}(\mathrm{I})$ ions onto F@SZS-5 (Figure 6c). Moreover, a higher value of $n$ (2.38) indicated a higher affinity between Cs(I) ions and F@SZS-5 active sites. The $K_{F}$ value for the adsorption of Cs(I) onto F@SZS-5 was obtained to be 4.74 . The analyses of the coefficient of the determination $\left(R^{2}\right)$ values with the used models showed that the experimental data can be well-fitted by the Langmuir model than the Freundlich model. In conclusion, the adsorption of the monovalent $\mathrm{Cs}$ (I) ions onto iron-doped sodium zirconosilicate (F@SZS-5) is based on different interactions such as ion exchange, hydrogen bonding, and physical adsorption [44,45].

The microporous F@SZS-5 sorbent can be applicable for removing monovalent Cs(I) ions from diluted aqueous solutions. In typical experimental conditions, a solution containing a mixture of $0.5 \mathrm{mg} \mathrm{L}^{-1} \mathrm{Cs}(\mathrm{I})$ ions and $2 \mathrm{mg} \mathrm{L}^{-1} \mathrm{Na}(\mathrm{I}), \mathrm{K}(\mathrm{I}), \mathrm{Li}(\mathrm{I}), \mathrm{Rb}(\mathrm{I}), \mathrm{Mg}(\mathrm{II})$, $\mathrm{Ca}(\mathrm{II}), \mathrm{Sr}(\mathrm{II}), \mathrm{Fe}(\mathrm{III}), \mathrm{Ni}(\mathrm{II}), \mathrm{Cr}(\mathrm{III}), \mathrm{Zn}(\mathrm{II}), \mathrm{La}(\mathrm{III}), \mathrm{U}(\mathrm{VI}), \mathrm{Th}(\mathrm{IV}), \mathrm{Cu}(\mathrm{II}), \mathrm{Ba}(\mathrm{II}), \mathrm{Pb}$ (II), and $\mathrm{Al}(\mathrm{III})$ each was used to estimate the applicability of the microporous F@SZS-5 sorbent for adsorption of $\mathrm{Cs}(\mathrm{I})$ ions. It is well-known that alkali metal ions tend to be more hydrated by decreasing the size. As a result, alkali metal ions such as $\mathrm{Li}(\mathrm{I}), \mathrm{Na}(\mathrm{I})$, and $\mathrm{K}(\mathrm{I})$ showed higher hydration in an aqueous solution compared to Cs(I) [40]. In contrast, divalent metal ions such as $\mathrm{Sr}(\mathrm{II})$ and $\mathrm{Ca}(\mathrm{II})$ also exerted a high impact on the adsorption of $\mathrm{Cs}(\mathrm{I})$ ions than the other divalent competing cations at low concentrations and among their competitive mixtures. This zeolite material could adsorb large cations like $\mathrm{Cs}(\mathrm{I})$ and $\mathrm{Sr}(\mathrm{II})$ from aqueous solutions but has a low adsorption behavior of small cations like $\mathrm{Li}, \mathrm{Na}$, and $\mathrm{Mg}$. The key reasons for this behavior are the hydration energies of the ions in solutions and those already occupying the structural channels and the difference of electrostatic bonding energy of the competing ions to the inner cavity surface [44].

The regeneration of the loaded F@SZS- 5 was carried out using different concentrations of nitric acid as compared to the optimal adsorption conditions of Cs(I) ions, which were carried out at $\mathrm{pH} 4-11$ (Figure $6 \mathrm{~d}$ ). The feasibility of reusability after a number of adsorption/desorption cycles was evaluated. Cs(I) ions were transported along the micropores to the bulk solution faster, and more than $97.8 \%$ was stripped within less than 15 min when contacting with $0.5 \mathrm{M} \mathrm{HNO}_{3}$. Subsequently, the regenerated F@SZS-5 was used for the adsorption of $\mathrm{Cs}(\mathrm{I})$ at the optimal experimental conditions of adsorption, and the results of 13 successive uptake experiments are presented. The competition of monovalent and divalent cations in solutions often increases the complication of adsorption reaction.

In general, inorganic materials, especially zirconium-containing materials, can be used in long- and short-term industrial applications, because these materials exhibit a tunable nature and remain stable at high temperatures, pressures, and radioactivity. Considering that global research efforts have been devoted to the removal of radioactive materials by using titanosilicates, we established a novel adsorbent to remove Cs(I) from aqueous solutions by utilizing a microporous iron-doped sodium zirconosilicate. The proposed sorbent not only provides a readily accessible avenue for the synthesis of a novel adsorbent that efficiently removes $\mathrm{Cs}(\mathrm{I})$, but also enhances selectivity and durability. Unique properties, such as large surface area-to-volume ratios, uniformly shaped pores, allow rapid removal of ultra-trace concentrations of Cs(I) ions, tuned selectivity, durability against radioactivity.

\section{Conclusions}

A novel high- $S_{A}$ iron-doped zeolite like sodium zirconosilicate has been successfully synthesized by a simple hydrothermal process assisted with Brij-35/urea. The chemical and textural characteristics of the synthesized materials were investigated using XRD, SEM, HR-TEM, STEM, and $\mathrm{N}_{2}$ adsorption/desorption measurements. The synthesized 
F@SZS-5 has great advantages of the large $\mathrm{S}_{\mathrm{A}}$-to-volume ratio, uniform micropores, and long-term stability and reusability. The results showed an extremely high ability of F@SZS-5 in removing the radioactive $\mathrm{Cs}(\mathrm{I})$ ions in ultra-dilute solutions with a maximum uptake of $21.5 \mathrm{mg} \mathrm{g}^{-1}$. The results of cesium ions adsorption were found to follow the pseudofirst-order kinetics, and the applied isotherms showed that the Langmuir model is a better description for the adsorption process than the Freundlich model.

Funding: This research received no external funding.

Acknowledgments: The author would like to thank Ahmed M. Daher, Nuclear Materials Authority for his support during this research work.

Conflicts of Interest: The author declare no conflict of interest.

\section{References}

1. Chukanov, N.V.; Pekov, I.V.; Rastsvetaeva, R.K. Crystal chemistry, properties and synthesis of microporous silicates containing transition elements. Russ. Chem. Rev. 2004, 73, 227-246. [CrossRef]

2. Turchkova, A.G.; Pekov, I.V.; Bryzgalov, I.A. Cation-exchange properties of natural zeolite-like sodium zirconosilicates: An experimental study in aqueous solutions at $80-90^{\circ} \mathrm{C}$ and $1 \mathrm{~atm}$. In Proceedings of the 19th General Meet of IMA, Kobe, Japan, 23-28 July 2006.

3. Grigor'eva, A.A.; Zubkova, N.V.; Pekov, I.V.; Kolitsch, U.; Pushcharovsky, D.Y.; Vigasina, M.F.; Giester, G.; Đorðevic, T.; Tillmanns, E.; Chukanov, N.V. Crystal chemistry of elpidite from Khan Bogdo (Mongolia) and its K-and Rb-exchanged forms. Crystallogr. Rep. 2011, 56, 832-841. [CrossRef]

4. Neronova, N.N.; Belov, N.V. Crystal structure of elpidite, $\mathrm{Na}_{2} \mathrm{ZrSi}_{6} \mathrm{O}_{15} \cdot\left(\mathrm{H}_{2} \mathrm{O}\right)_{3}$. Sov. Phys. Crystallogr. $1964,9,700-705$.

5. Cannillo, E.; Rossi, G.; Ungaretti, L. The crystal structure of elpidite. Am. Mineral. 1973, 58, 106-109.

6. Zubkova, N.V.; Ksenofontov, D.A.; Kabalov, Y.K.; Chukanov, N.V.; Nedel'ko, V.V. Dehydration-induced structural transformations of the microporous zirconosilicate elpidite. Inorg. Mater. 2011, 47, 506-512. [CrossRef]

7. Cametti, G.; Armbruster, T.; Nagashima, M. Dehydration and thermal stability of elpidite: An in-situ single crystal X-ray di_raction study. Microporous Mesoporous Mater. 2016, 227, 81-87. [CrossRef]

8. Nedelko, V.V.; Chukanov, N.V.; Pekov, I.V. Dehydration kinetics of the microporous zirconosilicate elpidite. Inorg. Mater. 2011, 47, 502-505. [CrossRef]

9. Agakhanov, A.A.; Pautov, L.A.; Karpenko, V.Y.; Sokolova, E.; Abdu, Y.A.; Hawthorne, F.C.; Pekov, I.V.; Siidra, I.O.; Yusupovite, O.I. $\mathrm{Na}_{2} \mathrm{Zr}\left(\mathrm{Si}_{6} \mathrm{O}_{15}\right)\left(\mathrm{H}_{2} \mathrm{O}\right)_{3}$, a new mineral species from the Darai-Pioz alkaline massif and its implications as a new microporous filter for large ions. Am. Mineral. 2015, 100, 1502-1508. [CrossRef]

10. Rocha, J.; Ferreira, P.; Lin, Z.; Agger, J.R.; Anderson, M.W. Synthesis and characterisation of a microporous zirconium silicate with the structure of petarasite. Chem. Commun. 1998, 1969-1970. [CrossRef]

11. Jale, S.R.; Ojo, A.; Fitch, F.R. Synthesis of microporous zirconosilicates containing $\mathrm{ZrO}_{6}$ octahedra and $\mathrm{SiO}_{4}$ tetrahedra. Chem. Commun. 1999, 41, 411-412. [CrossRef]

12. Grigorieva, A.A.; Pekov, I.V.; Bryzgalov, I.A. Ion-exchange properties of natural sodium zirconosilicate terskite. In Minerals as Advanced Materials I; Krivovichev, S.V., Ed.; Springer: Berlin/Heidelberg, Germany, 2008.

13. Berry, F.J.; Eadon, D.; Holloway, J.; Smart, L.E. Iron-doped zirconium silicate; Part 1.-The location of iron. J. Muter. Chem. 1996, 6, 221-225. [CrossRef]

14. Mahmoud, M.E.; Amira, M.F.; Seleim, S.M.; Abouelanwar, M.E. Solvent free microwave synthesis of nano polyaniline-zirconium silicate nanocomposite for removal of nitro derivatives. J. Ind. Eng. Chem. 2019, 77, 371-384. [CrossRef]

15. Frondel, C.; Collette, R.L. Hydrothermal synthesis of zircon, thorite and huttonite. Am. Mineral. 1959, 42, 759-765.

16. Sapozhnikov, A.N.; Kashaev, A.A. The crystal structure of calcined Ca-containing elpidite. Sov. Phys. Crystallogr. 1980, 25, 357-359.

17. Moosavi, A.; Aghaei, A. Comparison of solution combustion and co-precipitation methods in synthesis of iron zircon coral pigment. Pigment Resin Technol. 2010, 39, 203-207. [CrossRef]

18. Ozel, E.; Turan, S. Production of coloured zircon pigments from zircon. J. Eur. Ceram. Soc. 2007, 27, 1751-1757. [CrossRef]

19. Zubkova, N.V.; Nikolova, R.P.; Chukanov, N.V.; Kostov-Kytin, V.V.; Pekov, I.V.; Varlamov, D.A.; Larikova, T.S.; Kazheva, O.N.; Chervonnaya, N.A.; Shilov, G.V.; et al. Crystal chemistry and properties of elpidite and its exchanged forms. Minerals 2019, 9, 420. [CrossRef]

20. Choia, D.W.; Choy, K.L. The electrochemical effect of various Si/Zr molar ratios on anode materials in lithium-ion batteries. Dalton Trans. 2017, 46, 14226. [CrossRef] [PubMed]

21. Antoniazzi, C.; Guimarães de Castroa, E.; Anaissi, F.J. Zirconium oxide and iron zirconate obtained from citrus pectin and nitrates applied in the photo-fenton-like process. Orbital Electron. J. Chem. 2018, 10, 386-394. [CrossRef]

22. Fujiwara, H.; Kuramochi, H.; Nomura, K.; Maeseto, T. Behavior of radioactive cesium during incineration of radioactively contaminated wastes from decontamination activities in Fukushima. J. Environ. Radioact. 2017, 178-179, 290-296. [CrossRef] 
23. Mohapatra, P.K.; Bhattacharyya, A.; Manchanda, V.K. Selective separation of radio-cesium from acidic solutions using supported liquid membrane containing chlorinated cobalt dicarbollide (CCD) in phenyltrifluoromethyl sulphone (PTMS). J. Hazard. Mater. 2010, 181, 679-685. [CrossRef]

24. Tag El-Din, A.F.; El-Khouly, M.E.; Elshehy, E.A.; El-Said, W.A. Cellulose acetate assisted synthesis of worm-shaped mesopores of $\mathrm{MgP}$ ion-exchanger for cesium ions removal from seawater. Microporous Mesoporous Mater. 2018, 265, 211-218. [CrossRef]

25. Tag El-Din, A.F.; Elshehy, E.A.; Abd El-Magied, M.O.; Atia, A.A.; El-Khouly, M.E. Decontamination of radioactive cesium ions using ordered mesoporous monetite. RSC Adv. 2018, 8, 19041-19050. [CrossRef]

26. Awual, M.; Suzuki, S.; Taguchi, T.; Shiwaku, H.; Okamoto, Y.; Yaita, T. Selective cesium removal from radioactive liquid waste by crown ether immobilized new class conjugate sorbent. Chem. Eng. J. 2014, 242, 127-135. [CrossRef]

27. Awual, M.; Yaita, T.; Miyazaki, Y. A reliable hybrid sorbent for efficient radioactive cesium accumulation from contaminated wastewater. Sci. Rep. 2016, 6, 19937. [CrossRef] [PubMed]

28. Chen, R.Z.; Tanaka, H.; Kawamoto, T.; Miyuki, A.; Chikako, F.; Haitao, N.; Masato, K.; Masayuki, W.; Makoto, A.; Takuya, $\mathrm{N}$. Selective removal of cesium ions from wastewater using copper hexacyanoferrate nanofilms in an electrochemical system. Electrochim. Acta 2013, 87, 119-125. [CrossRef]

29. Kautsky, U.; Saetre, P.; Berglund, S.; Jaeschke, B. The impact of low and intermediate-level radioactive waste on humans and the environment over the next one hundred thousand years. J. Environ. Radioact. 2016, 151, 395-403. [CrossRef] [PubMed]

30. Abd El-Magied, M.O.; Elshehy, E.A.; Manaa, E.A.; Tolba, A.A.; Atia, A.A. Kinetics and thermodynamics studies on the recovery of thorium ions using amino resins with magnetic properties. Ind. Eng. Chem. Res. 2016, 55, 11338-11345. [CrossRef]

31. Ho, Y.S.; McKay, G. Pseudo-second order model for sorption processes. Process Biochem. 1999, 34, 451-465. [CrossRef]

32. Weber, W.J.; Morris, J.C.; Sanit, J. Kinetics of adsorption on carbon from solution. Eng. Div. 1963, 89, 31-60.

33. Alamudy, H.A.; Cho, K. Selective adsorption of cesium from an aqueous solution by a montmorillonite-prussian blue hybrid. Chem. Eng. J. 2018, 349, 595-602. [CrossRef]

34. Zheng, X.; Dou, J.; Yuan, J.; Qin, W.; Hong, X.; Ding, A. Removal of $\mathrm{Cs}^{+}$from water and soil by ammonium-pillared montmorillonite $/ \mathrm{Fe}_{3} \mathrm{O}_{4}$ composite. J. Environ. Sci. 2017, 56, 12-24. [CrossRef] [PubMed]

35. Ye, X.; Wu, Z.; Li, W.; Liu, H.; Li, Q.; Qing, B.; Guo, M.; Ge, F. Rubidium and cesium ion adsorption by an ammonium molybdophosphate-calcium alginate composite adsorbent. Colloids Surf. A 2009, 342, 76-83. [CrossRef]

36. Jang, S.-C.; Haldorai, Y.; Lee, G.-W.; Hwang, S.-K.; Han, Y.-K.; Roh, C.; Huh, Y.S. Porous three-dimensional grapheme foam/Prussian blue composite for efficient removal of radioactive 137Cs. Sci. Rep. 2015, 5, 17510. [CrossRef] [PubMed]

37. Sangvanich, T.; Sukwarotwat, V.; Wiacek, R.J.; Grudzien, R.M.; Fryxell, G.E.; Addleman, R.S.; Timchalk, C.; Yantasee, W. Selective capture of cesium and thallium from natural waters and simulated wastes with copper ferrocyanide functionalized mesoporous silica. J. Hazard. Mater. 2010, 182, 225-231. [CrossRef] [PubMed]

38. Attallah, M.F.; Abd-Elhamid, A.I.; Ahmed, I.M.; Aly, H.F. Possible use of synthesized nano silica functionalized by Prussian blue as sorbent for removal of certain radionuclides from liquid radioactive waste. J. Mol. Liq. 2018, 261, 379-386. [CrossRef]

39. Attallah, M.F.; Hassan, H.S.; Youssef, M.A. Synthesis and sorption potential study of $\mathrm{Al}_{2} \mathrm{O}_{3} \mathrm{ZrO}_{2} \mathrm{CeO}_{2}$ composite material for removal of some radionuclides from radioactive waste effluent. Appl. Radiat. Isot. 2019, 147, 40-47. [CrossRef] [PubMed]

40. Yang, H.; Li, H.; Zhai, J.; Sun, L.; Zhao, Y.; Yu, H. Magnetic prussian blue/graphene oxide nanocomposites caged in calcium alginate microbeads for elimination of cesium ions from water and soil. Chem. Eng. J. 2014, 246, 10-19. [CrossRef]

41. Tag El-Din, A.; Elshehy, E.A.; El-Khouly, M. Cellulose Acetate/EDTA-Chelator Assisted Synthesis of Ordered Mesoporous HAp Microspheres for Efficient Removal of Radioactive Species from Seawater. J. Environ. Chem. Eng. 2018, 16, 5845. [CrossRef]

42. Langmuir, I. The adsorption of gases on plane surfaces of glass, mica and platinum. J. Am. Chem. Soc. 1918, 40, 1361-1403. [CrossRef]

43. Freundlich, H.M.F. Über die adsorption in losungen. Z. Phys. Chem. 1906, 57, 385-470. [CrossRef]

44. Lee, J.; Park, S.-M.; Jeon, E.-K.; Baek, K. Selective and irreversible adsorption mechanism of cesium on illite. Appl. Geochem. 2017, 85, 188-193. [CrossRef]

45. Sherry, H.S. The ion exchange properties of a zeolites. In Ion Exchange, Aseries of Advances; Marinsky, J.A., Ed.; Marcel Dekker: New York, NY, USA, 1969; Volume 2, pp. 89-133. 